\title{
The Exploration and Research on the Undergraduate Innovation and Entrepreneurship Education Pattern
}

\author{
Xi Yu, Yingying Chen, Chunyang Zhao, Hainan Song* \\ School of Medical Image of Mudanjiang Medical University, Mudanjiang City, Heilongjiang, China \\ *Corresponding author
}

Keywords: Undergraduate; Innovation and Entrepreneurship education; Innovation and Entrepreneurship Culture.

\begin{abstract}
At present, innovation and entrepreneurship education has played a prominent role in the educational structure. In the new age, faced with the transition of economic structure, the change of personnel requirement, and the active demand of culture construction, all college students who play different roles in the society are required to complete innovation and entrepreneurship education pattern, which is also the priority of it. Breaking up traditional educational pattern and limitation of original way of thinking, intensifying construction of innovation and entrepreneurship culture, helping and guiding university students to build up proper innovation and entrepreneurship awareness and then effectively guide the future practice.
\end{abstract}

\section{Introduction}

In May, 2015, the General Office of the State Council issued "the implementation opinions on deepening the reform of innovation and entrepreneurship education in colleges and universities" which put forward accurate tasks and measures to deepen innovation and entrepreneurship educational reform, enhance quality of higher education and promote integrated development of students from nine aspects. The report of the 18th National Congress of Chinese Communist Party put forward innovation-driven strategy in full operation, our economic development motivation has converted from production factor drive, resource investment drive to innovation drive. According to the report of the 19th National Congress of Chinese Communist Party, innovation is the soul of the progress of a nation and the inexhaustible motivation of the prosperity of a country. It also puts forward that in the future China will enhance material, political, cultural, social and ecological civilization from every dimension and comes out new demands on innovative technology work and education methods. In order to carry out the innovation-driven development strategy, the country makes innovation and entrepreneurship of university students integrated into activities of 'mass entrepreneurship innovation ', making innovative technology combine with social development to improve innovative spirit and entrepreneurship ability. Innovation and entrepreneurship education of universities is not only a new posture of our contemporary universities active response to objective needs of national and social economic development, but only itself is an essential measure of the process of our contemporary universities transformation, which is an inevitable choice for our universities to break through traditional knowledge education pattern and become 
distinguished.

\section{Breaking through the Traditional Education Pattern}

Innovation and entrepreneurship education pattern of university students needs to adapt the needs of the times and culture, change stale educational idea. Innovation and entrepreneurship education is a rising subject and also a compulsory subject adapting the world development needs. Carrying out innovation and entrepreneurship education conforms to basic needs of current social economic development and talent cultivation, this requests that in the process of education, understanding subject orientation of innovation and entrepreneurship education and teaching targets correctly, combining general, professional and vocational education together organically on the basis of traditional education, executing innovation and entrepreneurship education as a kind of method, in the process of the practice, guiding and actively fostering students proper value concept and understanding faced with employment, job selection and entrepreneurship.If innovation and entrepreneurship education of university students is divorced from its true meaning and spirit, that will lose its conscience as well as limited in traditional way. As a rising educational subject, in the process of innovation and entrepreneurship educational development and application, we should pay more attention to people cultivation. The ideological construction of innovation and entrepreneurship carries out in the whole process of university students education and teaching, helping students form independent thought and rational understanding faced with employment and job selection in their process of education. In government, college and university, student and society these four levels, there also exists problems, like scattered distribution of policy, loss of innovation and entrepreneurship educational concept, weakness of capability and quality and thickness of environment atmosphere, as a result, we should take effective measures, intensify organizational leadership and policy guidance, perfect innovation and entrepreneurship education system, trigger students innovation and entrepreneurship vigor and create good atmosphere of innovation and entrepreneurship to drive innovation and entrepreneurship educational reformdevelopment of our colleges and universities.

\section{The New Method of Innovation and Entrepreneurship Education}

In our country, as the rapid development of innovation and entrepreneurship education in educational reform with economy and the change of personnel and demand pattern, the emphasis and voice of education and teaching reform become higher and higher. Innovation and entrepreneurship education as an important component of teaching gradually become perfect with social development needs and political security, making it become more and more important in the place of the colleges and universities education structure. University students as leaders in future are more keen to cognize, adapt and imagine new things, innovation and entrepreneurship educational idea is more adaptable to university students who are mentally agile and who have ability to creation and scientific research. Facing this special audience,indulging innovation and entrepreneurship cultural connotation in them and taking root in their ideas and spiritual cognitive on the basis of building up innovative awareness and idea sufficiently to give full play to innovation and entrepreneurship educational mission of the age. Focusing on fostering innovative abilities of student makers, adding 'Basic theory of entrepreneurship', 'Innovation case analysis','Makers expert lectures', 'Start-up management' etc. curriculum modules to make students fully understand the feasibility, importanceand necessity of innovation. Participating in industry of social activities actively, attracting social capital and adapting co-culture methods to carry out social practice. Innovation and entrepreneurship education as a new educational subject, pattern and structure, its bottom line is to execute innovation and entrepreneurship cultural construction. If it gets rid of the 
essence of cultural construction, it will come to an end of utility and vanity. From the cultural perspective, based on the analysis of current innovation and entrepreneurship educational structure, pattern and mechanism, finding present innovation and entrepreneurship educational reformational emphasis should put on the innovation and entrepreneurship cultural construction, without cultural foundation, innovation and entrepreneurship education which is out of step with the times is water without a source, a tree without roots. 'innovation and entrepreneurship culture refers to form in people's carrying out entrepreneurial activities in the way of innovation, the summation of values, ideological understanding, psychological states, environmental atmosphere, institutional system and way of act which social members generally agree with.' Although existing undergraduate education content satisfies part of their innovation and entrepreneurship needs, this satisfaction are very limited. With the promotion of national strategy 'public entrepreneurship and mass innovation.' Therefore,there needs systematically new educational idea, pattern and formation to satisfy students' development demands. Propelling innovation and entrepreneurship education consistently is an essential measure to perfect existing higher education content and an active choice made by colleges and universities in the new situation. Including innovation and entrepreneurship educational content into the higher educational content is beneficial to compensate for the existing undergraduate education deficiencies, rectify and reinforce students' urgent innovation and entrepreneurship education and meet students' needs of development sufficiently. Innovation and entrepreneurship educational construction of cultural connotation of colleges and universities not only involves innovation and entrepreneurship subject, but also embodies the meaning of educational practice ultimately. The key point of innovation and entrepreneurship lies in the cultivation of innovative awareness, the internalization of innovative spirit, the exploration of innovative ability and the systematic execution of innovative activities. The new method of innovation and entrepreneurship education lies in the establishment of core status of the connotative and cultural construction, innovation and entrepreneurship education isn't equal to encourage students to carry out innovation and entrepreneurship easily, at this stage innovation and entrepreneurship education still stays in traditional teaching method, relatively lags behind in the grasp of spiritual connotation and the teaching of practical meaning. How to break through the shackle and pass on innovation and entrepreneurship spirit to students is the new method.

\section{Current Problems and Countermeasures Existing in Innovation and Entrepreneurship Education}

Innovation and entrepreneurship education should stimulate the spirit of innovation and creation, employ modern educational means and platform, improve entrepreneurship education service format. In the context of education modernization, colleges and universities need to relocate innovation and entrepreneurship education. Facing innovation and entrepreneurship, what the most intuitive is the problems of employment and job selection. Former college students faced with innovation and entrepreneurship education exist certain misunderstandings, part of them blindly equate innovation and entrepreneurship with problems of employment and job selection instead of regarding it as a kind of idea rooting in heart transforming into action. The fundamental reason lies in the imperfection of education system, relative weakness of foundation and the degree of cognition of innovation and entrepreneurship needing to improve. Due to our country belonged to planned economy stage before the reform and opening-up, employment of college students had been followed the uniform distribution model so that innovation and entrepreneurship awareness of students hadn't formed in that period, schools even didn't have similar curriculum provision. After the reform and opening-up, with the market economy arising, entrepreneurship that so-called 'go into business' gradually appeared, our country carried out innovation and entrepreneurship 
education but only in the form of pilot in 1990s, nearly a decade our innovation and entrepreneurship education had rapid development. Facing our national innovation and entrepreneurship educational history problems and mission of the age, we should envisage problems of formalization and utilitarianism in it. Faced with problems should give full play to society, school and country, form good interaction and envisage problems of supply and demand, meanwhile, what is more important is to intensify cultural construction, national political approval, social companies' joint and organic combination of the standardization and modernization of college students' innovation and entrepreneurship education, which will be bound to solve our national current innovation and entrepreneurship problems and promote development of innovation and entrepreneurship education.

\section{References}

[1]Implementing Opinions of The General Office of the State Council on deepening the reform of innovation and entrepreneurship education in Institutions of Higher Learning . Document no.36 [2015] issued by the State Council.

[2] Huajian. Research on cultivating innovation and entrepreneurship culture in higher vocational colleges $[\mathrm{J}]$ Vocational and technical education in China, 2017. 